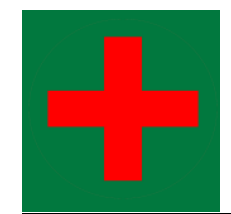

\title{
Perilaku Konsumsi Garam Dan Gula Pada Mahasiswa Fakultas Kedokteran Universitas Tadulako Angkatan 2020
}

\author{
Georgiana Patricia Tangkilisan ${ }^{1}$, Fitriah Handayani ${ }^{2}$, Ketut Suarayasa ${ }^{3}$, Yuli \\ Fitriana $^{4}$ \\ ${ }^{1}$ Program Studi Kedokteran, Fakultas Kedokteran, Universitas Tadulako, Palu, \\ Indonesia \\ ${ }^{2}$ Departemen Neurologi, Fakultas Kedokteran, Universitas Tadulako, Palu, Indonesia \\ ${ }^{3}$ Departemen Ilmu Kesehatan Masyarakat, Fakultas Kedokteran, Universitas Tadulako, \\ Palu, Indonesia \\ ${ }^{4}$ Departemen Histologi, Fakultas Kedokteran, Universitas Tadulako, Palu, Indonesia \\ Email: ${ }^{1}$ georgianapatricia20@gmail.com, ${ }^{2}$ fitriahhandayani.pspduntad@gmail.com, \\ ${ }^{3}$ suarayasa@yahoo.com, ${ }^{4}$ fitrianayuli5@gmail.com
}

\begin{abstract}
The objective of this research is to find out the knowledge, attitudes, and behavior of sugar and salt consumption among students at the medical faculty of Tadulako University in the 2020 batch. Methods: This research method is descriptive quantitative. The sample totaled 157 respondents selected through the total sampling technique. Results: A total of 156 respondents filled out the questionnaire. The results of the research are as follow: Students who have good knowledge about sugar and salt consumption on age 17 to 19 years of $66.4 \%$, age 20 to 22 years of $68.2 \%$. The characteristic of gender which has good knowledge about sugar and salt consumption is female of $71.3 \%$, male of $50 \%$. The characteristic of age which has a positive attitude about consuming sugar and salt is 17-19 years of 100\%, 20-22 years of 95.5\%. The female gender has a positive attitude about sugar and salt consumption of $99 \%$, the male is 100\%. Aged 17-19 years have positive behavior about consuming sugar and salt of $98.5 \%$; age 20-22 years of 95\%. The female gender has positive behavior regarding sugar and salt consumption of 97.5\%; male of $100 \%$. The top three foods frequently consumed by respondents were Siomay (16.4\%), Indomie fried noodle (15.7\%), and fried rice (10\%). The top three drinks frequently consumed by the respondents are PopIce (18.4\%), Nutrisari Orange (16.9\%), and Orange Juice (15.4\%). Conclusion: There is good knowledge, positive attitudes and positive behavior about salt and sugar consumption in medical students at the medical faculty of Tadulako University in the 2020 batch.
\end{abstract}

Keywords: Knowledge, Attitude, Behavior, Salt, Sugar, Consumption

\section{Abstrak}

Pendahuluan: Asupan garam dan gula yang meningkat merupakan salah satu faktor penyebab terjadinya penyakit tidak menular. Konsumsi garam yang berlebih merupakan penentu penting dari tekanan darah tinggi. Sejalan dengan itu, faktanya konsumsi gula dalam jumlah besar juga menyebabkan kualitas makanan menjadi buruk, obesitas, diabetes. Perilaku akurat terkait nutrisi yang akan diperoleh selama masa kuliah efektif dalam pencegahan penyakit yang mungkin terjadi di masa depan. Tujuan: Untuk 
mengetahui pengetahuan, sikap dan perilaku konsumsi garam dan gula pada mahasiswa kedokteran angkatan 2020 Universitas Tadulako. Metode: Penelitian ini bersifat deskriptif kuantitatif. Teknik pengambilan sampel dalam penelitian ini adalah total sampling dengan jumlah sampel penelitian yaitu 157 orang. Hasil: Sebanyak 156 responden yang mengisi kuesioner. Umur 17-19 tahun mempunyai pengetahuan baik tentang konsumsi garam dan gula yaitu (66,4\%); umur $20-22$ tahun $(68,2 \%)$. Jenis kelamin perempuan mempunyai pengetahuan baik tentang konsumsi garam dan gula (71,3\%); laki-laki yaitu (50\%). Umur 17-19 tahun mempunyai sikap positif tentang konsumsi garam dan gula (100\%); umur 20-22 tahun yaitu (95,5\%). Jenis kelamin perempuan mempunyai sikap positif tentang konsumsi garam dan gula (99\%); laki-laki (100\%). Umur 17-19 tahun mempunyai perilaku positif tentang konsumsi garam dan gula (98,5\%); umur 20-22 tahun yaitu (95\%). Jenis kelamin perempuan mempunyai perilaku positif tentang konsumsi garam dan gula (97,5\%); laki-laki (100\%). Tiga makanan teratas yang sering dikonsumsi responden adalah Siomay (16,4\%), Mie Indomie Goreng (15,7\%), dan Nasi Goreng (10\%). Tiga minuman teratas yang sering dikonsumsi responden adalah Pop Ice $(18,4 \%)$, Nutrisari Jeruk (16,9\%), dan Es Jeruk Peras $(15,4 \%)$. Kesimpulan: Terdapat pengetahuan yang baik, sikap yang positif dan perilaku yang positif tentang konsumsi garam dan gula pada mahasiswa kedokteran angkatan 2020 Universitas Tadulako.

Kata Kunci: Pengetahuan, Sikap, Perilaku, Garam, Gula dan Konsumsi

\section{PENDAHULUAN}

Garam merupakan gabungan senyawa kimia yang komponen utamanya ialah Natrium Klorida $(\mathrm{NaCl})$ sebesar $80 \%$ atau sama dengan garam dapur dan beberapa zat pengotor tambahan. ${ }^{1}$ Dimasa modern ini, garam menjadi salah satu kebutuhan utama dalam kehidupan setiap hari dan sumber mineral penting yang diperlukan oleh tubuh manusia serta kerap dipakai buat penyedap makanan. ${ }^{2}$ Gula adalah karbohidrat sederhana yang terdiri dari satu atau dua ikatan molekul sakarida yaitu monosakarida dan disakarida. ${ }^{3}$ Terdapat 2 macam gula yaitu gula yang berasal dari buah-buahan dan gula yang ditambahkan pada makanan. ${ }^{4}$

Asupan garam dan gula yang meningkat merupakan salah satu faktor penyebab terjadinya penyakit tidak menular, khususnya berkaitan dengan hipertensi, diabetes dan komplikasi kardiovaskular. Data World Health Organization (WHO) menunjukkan asupan garam di sebagian besar populasi menunjukkan bahwa garam konsumsi jauh lebih tinggi daripada yang dibutuhkan secara fisiologis. ${ }^{5}$

Kehidupan di perguruan tinggi adalah periode ketika beberapa perubahan signifikan terjadi dalam kehidupan mahasiswa. Hal ini terletak pada perubahan gaya hidup yang dapat menyebabkan beberapa perubahan dalam perilaku asupan gizi mahasiswa. ${ }^{6}$ Penelitian yang dilakukan (Nair et al. 2017) pada kelompok usia 18-25 tahun menunjukkan bahwa sebagian besar mahasiswa mulai mengalami perubahan perilaku asupan gizi seperti garam dan gula di tahun pertama perguruan tinggi. Perilaku ini menjadi sebuah tren peningkatan gaya hidup yang menetap di kalangan mahasiswa, dan kurangnya kesadaran dalam mengurus kesehatan. Daya tarik dari situasi ini dapat dipahami dengan melihat fakta bahwa bahkan mahasiswa kedokteran tidak mengetahui, atau memilih untuk mengabaikan, konsekuensi dari gaya hidup tidak sehat mereka. ${ }^{7}$ 
Perilaku akurat terkait nutrisi yang akan diperoleh selama masa kuliah efektif dalam pencegahan penyakit yang mungkin terjadi di masa depan. Penelitian tentang pengetahuan, sikap dan perilaku konsumsi garam dan gula pada mahasiswa kedokteran masih terbatas. Hal ini yang mendorong peneliti tertarik untuk melakukan penelitian karena ingin mengetahui apakah dimasa saat ini masih menyadari bahaya mengonsumsi garam dan gula secara berlebihan.

\section{METODE}

Penelitian ini bersifat deskriptif kuantitatif. Dalam penelitian ini teknik sampling yang digunakan adalah teknik total sampling. Sampel yang diambil dalam penelitian ini adalah seluruh mahasiswa fakultas kedokteran program studi kedokteran angkatan 2020 sejumlah 157 orang. Hasil data dianalisis menggunakan program SPSS versi 25. Normalitas distribusi data diuji dengan uji Kolmogorov Smirnov. Data yang diperoleh akan disajikan dalam bentuk tabel.

\section{HASIL}

Tabel 1. Karakteristik Responden

\begin{tabular}{lcc}
\hline \multicolumn{1}{c}{ Karakteristik } & Jumlah & Presentasi (\%) \\
\hline Umur & & \\
17-19 tahun & 134 & $(85,9)$ \\
20-22 tahun & 22 & $(14,1)$ \\
\hline Jenis Kelamin & & \\
Perempuan & 122 & $(78,2)$ \\
Laki-laki & 34 & $(21,8)$ \\
\hline $\mathrm{N}$ & 156 & $(100)$ \\
\hline
\end{tabular}

Berdasarkan tabel 1 diketahui bahwa responden yang berpartisipasi dalam penelitian yaitu sebanyak 156 orang (100\%) dengan rentang umur berkisar 17 sampai 22 tahun. Berdasarkan jenis kelamin yang terbanyak perempuan dengan presentasi $(78,2 \%)$.

Tabel 2. Distribusi Pengetahuan Berdasarkan Umur

\begin{tabular}{cccc} 
Umur & Frekuensi & $(\%)$ & Kategori \\
\hline 17-19 tahun & 89 & 66,4 & Baik \\
& 37 & 27,6 & Cukup \\
& 8 & 6 & Kurang \\
\hline 20-22 tahun & 15 & 68,2 & Baik \\
& 6 & 27,3 & Cukup \\
& 1 & 4,5 & Kurang \\
\hline
\end{tabular}

Berdasarkan tabel 2 diketahui bahwa sebagian besar mahasiswa kedokteran angkatan 2020 umur 17-19 tahun mempunyai pengetahuan baik tentang konsumsi garam dan gula yaitu sebanyak 89 mahasiswa (66,4\%), dan umur 20-22 tahun mempunyai pengetahuan baik tentang konsumsi garam dan gula yaitu sebanyak 15 mahasiswa $(68,2 \%)$.

Tabel 3. Distribusi Pengetahuan Berdasarkan Jenis Kelamin 


\begin{tabular}{cccc}
\hline $\begin{array}{c}\text { Jenis } \\
\text { Kelamin }\end{array}$ & Frekuensi & $(\%)$ & Kategori \\
\hline Perempuan & 87 & 71,3 & Baik \\
& 29 & 23,8 & Cukup \\
& 6 & 5 & Kurang \\
\hline Laki-laki & 17 & 50 & Baik \\
& 14 & 41,2 & Cukup \\
& 3 & 8,8 & Kurang \\
\hline
\end{tabular}

Berdasarkan tabel 3 diketahui bahwa sebagian besar mahasiswa kedokteran angkatan 2020 jenis kelamin perempuan mempunyai pengetahuan baik tentang konsumsi garam dan gula yaitu sebanyak 87 mahasiswa $(71,3 \%)$, dan jenis kelamin laki-laki mempunyai pengetahuan baik tentang konsumsi garam dan gula yaitu sebanyak 17 mahasiswa (50\%).

Tabel 4. Distribusi Sikap Berdasarkan Umur

\begin{tabular}{cccc}
\hline Umur & Jumlah & $(\%)$ & $\begin{array}{c}\text { Kategori } \\
\text { Sikap }\end{array}$ \\
\hline 17-19 tahun & 134 & 100 & Positif \\
\cline { 2 - 4 } & - & - & Negatif \\
\hline 20-22 tahun & 21 & 95 & Positif \\
\cline { 2 - 4 } & 1 & 5 & Negatif \\
\hline
\end{tabular}

Berdasarkan tabel 4 diketahui bahwa semua mahasiswa kedokteran angkatan 2020 umur 17-19 tahun mempunyai sikap positif tentang konsumsi garam dan gula yaitu sebanyak 156 mahasiswa (100\%). Sedangkan untuk umur 20-22 tahun hampir seluruhnya memiliki sikap positif tentang konsumsi garam dan gula yaitu sebanyak 21 mahasiswa $(95 \%)$.

Tabel 5. Distribusi Sikap Berdasarkan Jenis Kelamin

\begin{tabular}{cccc}
\hline Jenis Kelamin & Jumlah & $(\%)$ & $\begin{array}{c}\text { Kategori } \\
\text { Sikap }\end{array}$ \\
\hline \multirow{2}{*}{ Perempuan } & 121 & 99 & Positif \\
\cline { 2 - 4 } & 1 & 1 & Negatif \\
\hline \multirow{2}{*}{ Laki-laki } & 34 & 100 & Positif \\
\cline { 2 - 4 } & - & - & Negatif \\
\hline
\end{tabular}

Berdasarkan tabel 5 diketahui bahwa hampir seluruh mahasiswa kedokteran angkatan 2020 jenis kelamin perempuan mempunyai sikap positif tentang konsumsi garam dan gula yaitu sebanyak 121 mahasiswa (99\%). Sementara itu, untuk jenis kelamin laki-laki semuanya memiliki sikap positif tentang konsumsi garam dan gula yaitu sebanyak 34 mahasiswa (100\%).

Tabel 6. Distribusi Perilaku Berdasarkan Umur

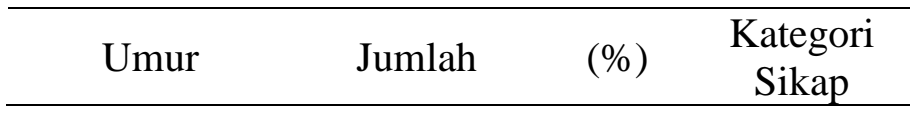




\begin{tabular}{cccc}
\hline 17-19 tahun & 132 & 98,5 & Positif \\
\cline { 2 - 4 } & 2 & 1,5 & Negatif \\
\hline \multirow{2}{*}{ 20-22 tahun } & 21 & 95 & Positif \\
\cline { 2 - 4 } & 1 & 5 & Negatif \\
\hline
\end{tabular}

Berdasarkan tabel 6 diketahui bahwa hampir seluruh mahasiswa kedokteran angkatan 2020 umur 17-19 tahun mempunyai perilaku positif tentang konsumsi garam dan gula yaitu sebanyak 132 mahasiswa (98,5\%). Sedangkan untuk umur 20-22 tahun juga hampir seluruhnya memiliki perilaku positif tentang konsumsi garam dan gula yaitu sebanyak 21 mahasiswa (95\%).

Tabel 7. Distribusi Perilaku Berdasarkan Jenis Kelamin

\begin{tabular}{cccc}
\hline Jenis Kelamin & Jumlah & $(\%)$ & $\begin{array}{c}\text { Kategori } \\
\text { Sikap }\end{array}$ \\
\hline \multirow{2}{*}{ Perempuan } & 119 & 97,5 & Positif \\
\cline { 2 - 4 } & 3 & 2,5 & Negatif \\
\hline \multirow{2}{*}{ Laki-laki } & 34 & 100 & Positif \\
\cline { 2 - 4 } & - & - & Negatif \\
\hline
\end{tabular}

Berdasarkan tabel 7 diketahui bahwa hampir seluruh mahasiswa kedokteran angkatan 2020 jenis kelamin perempuan mempunyai perilaku positif tentang konsumsi garam dan gula yaitu sebanyak 119 mahasiswa (97,5\%). Sementara itu, untuk jenis kelamin laki-laki semuanya memiliki perilaku positif tentang konsumsi garam dan gula yaitu sebanyak 34 mahasiswa (100\%).

Tabel 8. Distribusi Makanan

\begin{tabular}{clcc}
\hline $\begin{array}{c}\text { No } \\
\text { Item }\end{array}$ & \multicolumn{1}{c}{ Nama } & Frekuensi & $(\%)$ \\
\hline 1 & Siomay & 84 & 16,4 \\
\hline 2 & Mie Indomie Goreng & 80 & 15,7 \\
\hline 3 & Nasi Goreng & 51 & 10 \\
\hline 4 & Gorengan & 50 & 9,8 \\
\hline 5 & Nasi Ayam Geprek & 49 & 9,6 \\
\hline 6 & Oreo & 37 & 7,2 \\
\hline 7 & Mie Sedap Goreng & 31 & 6,1 \\
\hline 8 & Gado-gado & 30 & 5,9 \\
\hline 9 & Mie Sedap Soto & 26 & 5,1 \\
\hline 10 & Biskuit Better & 21 & 4,1 \\
\hline 11 & Nasi Telur Goreng & 20 & 3,9 \\
\hline 12 & Binte & 18 & 3,5 \\
\hline 13 & Biskuit Goriorio & 7 & 1,4 \\
\hline 14 & Chaca & 7 & 1,4 \\
\hline & $\quad$ Total & 511 & 100 \\
\hline
\end{tabular}


Berdasarkan tabel 8 diketahui bahwa 3 makanan teratas yang sering dikonsumsi mahasiswa kedokteran angkatan 2020 yaitu Siomay sebanyak 84 pilihan (16,4\%), Mie Indomie Goreng sebanyak 80 pilihan $(15,7 \%)$, dan Nasi Goreng sebanyak 51 pilihan $(10 \%)$.

Tabel 9. Distribusi Minuman

\begin{tabular}{cccc}
\hline $\begin{array}{c}\text { No } \\
\text { Item }\end{array}$ & Nama & Frekuensi & $(\%)$ \\
\hline 1 & Pop Ice & 61 & 18,4 \\
\hline 2 & Nutrisari Jeruk & 56 & 16,9 \\
\hline 3 & Es Jeruk Peras & 51 & 15,4 \\
\hline 4 & Milo Susu & 44 & 13,3 \\
\hline 5 & Nutrisari Jeruk Nipis & 34 & 10,3 \\
\hline 6 & Kopi Good day & 33 & 10 \\
\hline 7 & Teh Poci & 17 & 5,1 \\
\hline 8 & Drink Beng-beng & 13 & 3,9 \\
\hline 9 & Drink Chocolatos & 11 & 3,3 \\
\hline 10 & Nu Tea & 11 & 3,3 \\
\hline & Total & 331 & 100 \\
\hline
\end{tabular}

Berdasarkan tabel 9 diketahui bahwa 3 minuman teratas yang sering dikonsumsi mahasiswa kedokteran angkatan 2020 yaitu Pop Ice sebanyak 61 pilihan (18,4\%), Nutrisari Jeruk sebanyak 56 pilihan (16,9\%), dan Es Jeruk Peras sebanyak 51 pilihan $(15,4 \%)$.

\section{PEMBAHASAN}

\section{Pengetahuan, Sikap, Dan Perilaku}

Dari hasil penelitian tabel pengetahuan menunjukkan pengetahuan mahasiswa kedokteran angkatan 2020 tentang konsumsi garam dan gula berdasarkan jenis kelamin perempuan sebagian besar adalah baik tentang konsumsi garam dan gula yaitu sebanyak 87 mahasiswa (71,3\%). Berdasarkan umur 20-22 tahun sebagian besar adalah baik tentang konsumsi garam dan gula yaitu sebanyak 15 mahasiswa $(68,2 \%)$.

Hasil penelitian ini di dukung oleh hasil penelitian yang dilakukan oleh Grimes et al (2017) umumnya wanita lebih berpengetahuan, dengan proporsi yang lebih besar menyadari asupan garam dan gula tinggi dalam suatu populasi, bersama dengan sumber makanan utama garam dan gula dan kesehatan yang berhubungan dengan kelebihan asupan.

Hasil penelitian ini di dukung oleh hasil penelitian yang dilakukan (Ismail et al. 2019) menunjukkan bahwa partisipan yang berusia lebih tua memiliki tingkat pengetahuan gizi yang lebih tinggi dan jenis kelamin perempuan lebih sadar akan kesehatan, sehingga memiliki skor pengetahuan konsumsi garam dan gula yang lebih tinggi dibandingkan dengan jenis kelamin laki-laki. ${ }^{8}$ 
Pengetahuan dapat dipengaruhi oleh beberapa faktor, salah satunya yaitu usia. Usia dapat mempengaruhi pengetahuan seseorang, karena semakin bertambahnya usia maka semakin berkembang pula daya tangkap dan pola pikir seseorang sehingga pengetahuan yang diperoleh pun semakin baik. Faktor lainnya yang mempengaruhi tingkat pengetahuan seseorang adalah tingkat pendidikan, pengalaman, informasi, lingkungan budaya, dan sosial ekonomi. ${ }^{9}$

Dari hasil penelitian tabel distribusi sikap menunjukkan sikap mahasiswa kedokteran angkatan 2020 tentang konsumsi garam dan gula pada jenis kelamin perempuan memiliki sikap positif lebih mendominasi dibandingkan jenis kelamin lakilaki yaitu sebanyak 121 mahasiswa (99\%). Sementara itu, berdasarkan umur 17-19 tahun mempunyai sikap positif tentang konsumsi garam dan gula lebih besar dibanding umur 20-22 tahun yaitu sebanyak 156 mahasiswa (100\%).

Dari hasil penelitian tabel distribusi perilaku menunjukkan perilaku mahasiswa kedokteran angkatan 2020 tentang konsumsi garam dan gula pada jenis kelamin perempuan memiliki perilaku positif lebih banyak dibandingkan jenis kelamin laki-laki yaitu sebanyak 119 mahasiswa (97,5\%). Kemudian, berdasarkan umur 17-19 tahun mempunyai perilaku positif tentang konsumsi garam dan gula lebih besar dibanding umur 20-22 tahun yaitu sebanyak 132 mahasiswa $(98,5 \%)$.

Hasil penelitian ini di dukung oleh hasil penelitian yang dilakukan (Delia et al. 2019) terdapat perbedaan sikap dan perilaku jenis kelamin terhadap konsumsi garam dan gula. Jenis kelamin perempuan lebih sering mengurangi penggunaan garam dan gula dan lebih siap melakukan sesuatu untuk mengontrol asupan garam dan gula. ${ }^{10}$

Pola makan dan sikap individu terhadap konsumsi gula tambahan dipengaruhi oleh beberapa faktor, seperti pengetahuan, suasana hati, dan harga. Misalnya, pengetahuan yang terbatas tentang klasifikasi gula dan pemanis makanan pada label makanan (gula alami, gula tambahan, dan pemanis buatan) terbukti dalam sebuah penelitian yang dilakukan di Irlandia. ${ }^{11}$

\section{Pola Konsumsi Makanan Dan Minuman}

World Health Organization (WHO) merekomendasikan untuk asupan natrium $<2$ $\mathrm{g} /$ hari $=$ garam $5 \mathrm{~g} /$ hari dan membatasi asupan gula tambahan $<10 \%$ dari total asupan energi (12,5 sendok teh) untuk mencegah karies gigi dan obesitas dan menyarankan pengurangan lebih lanjut hingga dibawah 5\% dari total asupan energi ( $25 \mathrm{~g}=6$ sendok teh). ${ }^{12}$ Sementara itu, menurut The Scientific Committee of the Spanish Agency for Food Safety and Nutrition (AESAN) merekomendasikan asupan rendah natrium $(<2 \mathrm{~g} / \mathrm{hari}$, $\sim 1$ sendok teh garam). ${ }^{13}$ Kemudian, rekomendasi asupan gula yaitu $<30$ g/hari dan hindari makanan dengan tambahan gula. Berdasarkan Recommended Energy Intake/Recommended Nutrient Intake (REI/RNI) total kebutuhan kalori untuk dewasa umur 19-29 tahun yaitu laki-laki : 2.530 kalori dan perempuan : 1.930 kalori. $^{14}$

Dari hasil distribusi tabel makanan menunjukkan 3 makanan teratas yang sering dikonsumsi mahasiswa kedokteran angkatan 2020 yaitu Siomay sebanyak 84 pilihan (16,4\%), Mie Indomie Goreng sebanyak 80 pilihan (15,7\%), dan Nasi Goreng sebanyak 51 pilihan $(10 \%)$. Berdasarkan hasil penelitian tersebut didapatkan hasil perhitungan 
asupan garam dan gula dalam setiap sajian menurut rekomendasi WHO, AESAN, dan REI/RNI sebagai berikut :

Siomay mengandung natrium $264 \mathrm{mg}$ dan gula $0,19 \mathrm{~g}$ dengan total kalori per sajian $(75 \mathrm{~g})$ yaitu 103 kalori. ${ }^{15} \mathrm{Hal}$ ini menunjukkan untuk kandungan natrium sebanyak $264 \mathrm{mg}$ menyumbang $13 \%$ dari total natrium yang direkomendasikan. Sementara itu, untuk kandungan gula yang tercantum per sajian yaitu $0,19 \mathrm{~g}$ masih dalam batas aman. Siomay menyumbang kalori sebanyak $4 \%$ untuk laki-laki dan 5\% untuk perempuan dari total asupan kalori per hari.

Hasil penelitian ini di dukung oleh hasil penelitian yang dilakukan (Rasyid dkk. 2018) kelompok makanan yang proses pengolahannya direbus, dikukus dan dipanggang seperti cilok, jasuke, siomay dan roti bakar memiliki kadar lemak yang lebih rendah daripada jajanan yang digoreng. Rerata kadar lemak pada empat kelompok jajanan ini tidak berbeda signifikan. Dari empat kelompok ini, siomay menunjukkan kadar lemak yang paling tinggi. Hal ini mungkin karena penyajiannya menggunakan saus kacang, seperti halnya pada batagor sehingga membuat kadar lemak pada siomay lebih tinggi daripada cilok, jasuke dan roti bakar. Jika siomay dikonsumsi tanpa menggunakan saus kacang maka kemungkinan kadar lemaknya menurun banyak dan lebih sehat untuk dikonsumsi. ${ }^{16}$

Mie indomie goreng mengandung natrium $680 \mathrm{mg}$ natrium dan gula $0,19 \mathrm{~g}$ dengan total kalori per sajian ( $80 \mathrm{~g}$ ) yaitu 350 kalori. ${ }^{15} \mathrm{Hal}$ ini menunjukkan untuk kandungan natrium sebanyak $680 \mathrm{mg}$ menyumbang $34 \%$ dari total asupan natrium yang direkomendasikan. Sementara itu, untuk kandungan gula yang tercantum dalam kemasan yaitu 6 g menyumbang 20\% dari total asupan gula yang direkomendasikan. Mie instan menyumbang kalori sebanyak $14 \%$ untuk laki-laki dan $18 \%$ untuk perempuan dari total asupan kalori per hari. Namun, karena mie instan tinggi karbohidrat olahan dan rendah serat hal ini berkorelasi dengan tingginya indeks glikemik (GI).

Menurut seorang ahli gizi dan dietisien, mengatakan bahwa mengonsumsi mie instan setiap hari tidak dianjurkan karena kandungan nutrisinya yang tidak lengkap, meski mengenyangkan. Ia menyarankan untuk mengonsumsi mie instan seminggu sekali. Mie instan belum diakui sebagai makanan pokok karena belum memenuhi kebutuhan nutrisi tubuh. Mie terbuat dari tepung terigu dengan kandungan karbohidrat yang besar, serta sedikit mengandung protein, vitamin, dan mineral. Nutrisi mie instan dapat terpenuhi jika ditambah dengan sayuran dan sumber protein. ${ }^{17}$

Nasi goreng mengandung natrium $618 \mathrm{mg}$ dan gula 1,13 g dengan total kalori per sajian (149 g) yaitu 250 kalori. ${ }^{15}$ Hal ini menunjukkan untuk kandungan natrium sebanyak $618 \mathrm{mg}$ menyumbang $31 \%$ dari total natrium yang direkomendasikan. Sementara itu, untuk kandungan gula per sajian yaitu 1,13 g masih dalam batas aman. Nasi goreng menyumbang kalori sebanyak $10 \%$ untuk laki-laki dan $13 \%$ untuk perempuan dari total asupan kalori per hari.

Makanan yang digoreng memiliki efek kardiovaskular yang merugikan. Sebuah studi cross-sectional di Spanyol menemukan bahwa makanan yang digoreng dengan minyak yang digunakan kembali dikaitkan dengan prevalensi tinggi hipertensi. Asupan makanan yang digoreng juga dikaitkan dengan berat badan berlebih dan risiko obesitas serta diabetes tipe 2 di antara pria dan wanita. Penggorengan meningkatkan jumlah 
kolesterol dan produk oksidasi lipid lainnya terutama saat memasak daging, ikan, dan sayuran, dibandingkan dengan makanan kaya karbohidrat. ${ }^{18}$

Dari hasil distribusi tabel minuman menunjukkan 3 minuman teratas yang sering dikonsumsi mahasiswa kedokteran angkatan 2020 yaitu Pop Ice sebanyak 61 pilihan $(18,4 \%)$, Nutrisari Jeruk sebanyak 56 pilihan (16,9\%), dan Es Jeruk Peras sebanyak 51 pilihan $(15,4 \%)$. Berdasarkan hasil penelitian tersebut didapatkan hasil perhitungan asupan garam dan gula dalam setiap sajian menurut rekomendasi WHO, AESAN, dan REI/RNI sebagai berikut :

Pop Ice mengandung natrium $75 \mathrm{mg}$ dan gula $17 \mathrm{~g}$ dengan total kalori per sajian (26 g) yaitu 110 kalori. ${ }^{15}$ Hal ini menunjukkan untuk kandungan natrium sebanyak 75 mg masih dalam batas aman. Sementara itu, untuk kandungan gula yang tercantum dalam kemasan yaitu 17 g menyumbang 57\% atau setengah dari kebutuhan harian gula yang direkomendasikan. Pop Ice menyumbang kalori sebanyak $4 \%$ untuk laki-laki dan $6 \%$ untuk perempuan dari total asupan kalori per hari.

Nutrisari Jeruk mengandung natrium $20 \mathrm{mg}$ dan gula $12 \mathrm{~g}$ dengan total kalori per sajian (14 g) yaitu 50 kalori. ${ }^{15}$ Hal ini menunjukkan untuk kandungan natrium sebanyak $20 \mathrm{mg}$ masih dalam batas aman. Sementara itu, untuk kandungan gula yang tercantum dalam kemasan yaitu 12 g menyumbang 40\% atau hampir setengah dari kebutuhan harian gula yang direkomendasikan. Nutrisari Jeruk menyumbang kalori sebanyak $2 \%$ untuk laki-laki dan 3\% untuk perempuan dari total asupan kalori per hari.

Es Jeruk Peras mengandung natrium $2 \mathrm{mg}$ dan gula 20,83 g dengan total kalori per sajian (1 gelas) yaitu 112 kalori. ${ }^{15}$ Hal ini menunjukkan untuk kandungan natrium sebanyak $2 \mathrm{mg}$ masih dalam batas aman. Sementara itu, untuk kandungan gula yang tercantum yaitu 20,83 g menyumbang $69 \%$ atau hampir seluruh dari kebutuhan harian gula yang direkomendasikan. Es Jeruk Peras menyumbang kalori sebanyak 4\% untuk laki-laki dan $6 \%$ untuk perempuan dari total asupan kalori per hari.

Jumlah gula yang sangat tinggi ditemukan di minuman yang dimaniskan, makanan ringan bergula, permen, cokelat, dan bahkan dalam susu anak-anak, dengan produsen makanan sering menambahkan 10 kategori gula ke dalam makanan buatan pabrik. Gula tambahan ini termasuk glukosa, dextrosa, fruktosa, HFCS, gula sehari-hari (sukrosa), gula malt (maltosa), maltodekstrin, dan gula yang ditemukan dalam madu, sirup, jus buah, dan konsentrat jus buah. ${ }^{19}$

Keterbatasan waktu dan kenyamanan mendorong pilihan makanan dan minuman meningkat selama bertahun-tahun. Minuman manis telah menjadi kategori makanan dan minuman kemasan yang sangat populer di pasaran. Produk minuman dengan jumlah gula yang tinggi sekarang merupakan bagian dari agen lain yang dapat meningkatkan efek sensorik yang menyenangkan dari makanan yang terasa manis. Sementara rasa manis menyenangkan untuk dicicipi dan karena itu meningkatkan seluruh pengalaman minum minuman. ${ }^{20}$

Menurut PMK No. 41 tahun 2014 tentang Pedoman Gizi Seimbang, prinsip gizi seimbang terdiri dari 4 (empat) pilar yang pada dasarnya merupakan rangkaian upaya untuk menyeimbangkan antara zat gizi yang keluar dan zat gizi yang masuk dengan memantau berat badan secara teratur. Cara menerapkan pesan ini adalah dengan mengonsumsi lima kelompok pangan setiap hari atau setiap kali makan. Kelima 
kelompok pangan tersebut adalah makanan pokok, lauk-pauk, sayuran, buah-buahan dan minuman. Mengonsumsi lebih dari satu jenis untuk setiap kelompok makanan (makanan pokok, lauk pauk, sayuran dan buah-buahan) setiap kali makan akan lebih baik. $^{21}$

Pola makan menjadi perilaku paling penting yang dapat mempengaruhi keadaan gizi. Hal ini disebabkan karena kuantitas dan kualitas makanan dan minuman yang dikonsumsi akan mempengaruhi asupan gizi sehingga akan mempengaruhi kesehatan individu dan masyarakat. Gizi yang optimal sangat penting untuk pertumbuhan normal serta perkembangan fisik dan kecerdasan bayi, anak-anak, serta seluruh kelompok umur. Gaya hidup modern yang saat ini dianut oleh manusia cenderung membuat manusia menyukai hal-hal yang instan. Akibatnya, mereka cenderung malas beraktivitas fisik dan gemar mengonsumsi makanan dan minuman yang instan, yang memiliki kandungan garam dan gula yang tinggi. ${ }^{22}$

\section{KESIMPULAN DAN SARAN}

Terdapat pengetahuan yang baik, sikap yang positif dan perilaku yang positif tentang konsumsi garam dan gula pada mahasiswa kedokteran angkatan 2020 Universitas Tadulako. Dengan adanya hasil penelitian ini, diharapkan pihak-pihak yang terkait dapat memberikan informasi bermanfaat dan menarik pada mahasiswa kedokteran mengenai konsumsi garam dan gula serta evaluasi pada kantin di area kampus untuk lebih meningkatkan produk olahan makanan atau minuman yang lebih sehat.

\section{DAFTAR PUSTAKA}

Umam, F. 2019. Pemurnian Garam dengan Metode Rekristalisasi di Desa Bunder Pamekasan untuk Mencapai SNI Garam Dapur. Jurnal Ilmiah Pangabdhi, 5(1), 24-27. https://doi.org/10.21107/pangabdhi.v5i1.5161

Rini, H. M., Pramono, D., Nugraheni, A. 2017. Faktor - Faktor Yang Mempengaruhi Tingkat Konsumsi Garam Beryodium Pada Ibu Rumah Tangga Di Desa gembong Kecamatan Gembong Kabupaten Pati. Jurnal Kedokteran Diponegoro, 6(2), 632-644. https://doi.org/10.14710/dmj.v6i2.18581

Firdiansyah, R. D., Habibah, S. S., Utami, N. K. 2020. Pengaruh Mengkonsumsi Karbohidrat Sederhana (Biskuit Kelapa) Dan Karbohidrat Kompleks (Pisang Ayam) Terhadap pH Saliva. Jurnal Terapis Gigi dan Mulut, 1(2), 5761. https://jurnal-terapisgigimulut.com

Atmarita., Jahari, A. B., Sudikno., Soekatri, M. 2016. Asupan Gula, Garam, Dan Lemak di Indonesia: Analisis Survei Konsumsi Makanan Individu (SKMI) 2014. Jurnal Gizi Indonesia, 39(1), 1-14. https://ejournal.persagi.org/go/

Idelson, P. I., Delia, L., Cairella, G., Sabino, P., Scalfi, L., Fabbri, A., et al. 2020. Salt and Health: Survey on Knowledge and Salt Intake Related Behaviour in Italy. Journal Nutrients, 12(2), 1-17. https://doi.org/10.3390/nu12020279 
Ozdogan, Y., Yardimci, H., Ozcelik, A. O. 2018. Assessment of Nutrition Knowledge among University Students in Ankara. Journal of Scientific Research \& Reports, 20(4), 1-8. DOI: $10.9734 /$ JSRR/2018/43782

Nair, L. M., Madhu, B., Srinath, K. M., Gopinath, A., Yadav, K. 2017. Magnitude of behavioural risk factors for cardiovascular diseases among college going young adults (18-25 years) in Mysuru, Karnataka, India. 4(1), 65- 72.

DOI: http://dx.doi.org/10.18203/2394-6040.ijcmph20164713

Ismail, L. C., Hashim, M., Jarrar, A. H., Mohamad, M. N., Saleh, S. T., Jawish, N.,Bekdache, M., Albaghli, H., Kdsi, D., Aldarweesh, D., Dhaheri, A. S. A.2019. Knowledge, Attitude, and Practice on Salt and Assessment of Dietary Salt and Fat Intake among University of Sharjah Students. Journal Nutrients, 11(5), 941. DOI:10.3390/nu11050941

Waryana, W., Sitasari, A., Febritasanti, D. W. 2019. Intervensi media video berpengaruh pada pengetahuan dan sikap remaja putri dalam mencegah kurang energi kronik. Aceh Nutrition Journal, 4(1), 1-10. https://ejournal.poltekkesaceh.ac.id/index.php/an/article/view/154

Delia, L., Brajovic, M., Klisic, A., Breda, J., Jewell, J., Cadjenovic, V., et al. 2019. Sodium and Potassium Intake, Knowledge Attitudes and Behaviour Towards Salt Consumption Amongst Adults in Podgorica, Montenegro. Journal Nutrients, 11(1), 1-12. https://doi.org/10.3390/nu11010160

Mumena, W. A., Alamril, A. A., Mahrous1, A. A., Alharbi1, B. M., Almohaimeed1, J. S., Hakeem1, I. M., Kutbi, H. A. 2020. Knowledge, Attitudes, and Practices Towards Added Sugar Consumption among Female Undergraduate Students in Madinah, Saudi Arabia: A Cross- Sectional Study. Journal Nutrition, 79, 112. https://doi.org/10.1016/j.nut.2020.110936

WHO. 2015. Guideline : Sugars intake for adults and children. Geneva: World Health Organization.

Camara, M., Giner, R. M., Fandos, E. G., Garcia, E. L., Manes, J., Portillo, M. P. 2021. Food-Based Dietary Guidelines around the World: A Comparative Analysis to Update AESAN Scientific Committee Dietary Recommendations. Journals Nutrients, 13(9), 1-14. ～https://doi.org/10.3390/nu13093131

Gomez, K. G., Ignacio, M. S. E. 2020. Adequacy of Food Aid Packs Provided during Natural Disasters: A Provincial Case Study. The National Health Science Journal, 54(5). DOI: https://doi.org/10.47895/amp.v54i5.2218

Fat Secret Indonesia. Database Makanan dan Penghitung Kalori. 2021. http://www.fatsecret.co.id/kalori-gizi

Rasyid, H. A., Santoso, S. A., Araminta, M. P. 2018. Kadar Lemak Jajanan Mahasiswa Fakultas Kedokteran Universitas Brawijaya. Indonesian Journal of Human Nutrition, 5(1), 1-10. DOI: http://dx.doi.org/10.21776/ub.ijhn.2018.005.01.1 
Hardiyanti, N., Maryanti, R., Wulandary, V., Irawan, A. R. 2022. Knowledge and Actions Regarding Consumption of Instant Noodle in Elementary School Student Before and After the Provision of Educational Video. ASEAN Journal of Science and Engineering Education, 2(3), 317-324. https://ejournal.upi.edu/

Hu, P., Li, Y., Campos, H. 2018. Fried food intake and risk of nonfatal acutemyocardial infarction in the Costa Rica Heart Study. PLoS One, 13(2). doi: 10.1371/journal.pone.0192960

Haque, M., McKimm, J., Sartelli, M., Samad, N., Haque, S. Z., Bakar, M. A. 2020. A narrative review of the effects of sugar-sweetened beverages on human health : A key global health issue. J Popul Ther Clin Pharmacol, 27(1). DOI: 10.15586/jptcp.v27i1.666

Wisuantari, N. P. P., Sekarasih, L. 2020. Health Literacy Program to Reduce the Consumption of Sugary Drinks by Middle School Students in Jakarta. Makara Hubs-Asia, 24(2), 129-140. https://doi.org/https://doi.org/10.7454/hubs.asia.1071019

Depkes. 2014. Permenkes Republik Indonesia No 41, Pedoman Gizi Seimbang. Jakarta : Depkes RI 2014

Ratnawati, Aswad, A. 2019. Efektivitas Terapi Pijat Refleksi dan Terapi Benson terhadap Penurunan Tekanan Darah pada Penderita Hipertensi. Jambura Health and Sport Journal, 1(1), 40-47. http://ejurnal.ung.ac.id/index.php/jhsj/article/view/2052 